\title{
Factors associated with the use of physical restraint in intensive care patients
}

\author{
Fatores associados à utilização de restrição mecânica em \\ pacientes de terapia intensiva \\ Factores asociados con la utilización de restricción mecánica \\ en pacientes de cuidados intensivos
}

How to cite this article:

Zulian LR, Mori S, Teraoka EC, Miyasaki VYK, Zanei SSV, Whitaker IY. Factors associated with the use of physical restraint in intensive care patients. Rev Esc Enferm USP. 2020;54:e03571. doi: https://doi.org/10.1590/S1980-220X2018058503571

\section{Luana Rosas Zulian ${ }^{1}$ \\ Satomi Mori² \\ Eliana Cavalari Teraoka² \\ Vanessa Yukie Kita Miyasaki² \\ Suely Sueko Viski Zanei² \\ Iveth Yamaguchi Whitaker²}

${ }^{1}$ Hospital Samaritano, Unidade de Terapia Intensiva, São Paulo, SP, Brazil.

${ }^{2}$ Universidade Federal de São Paulo, Escola Paulista de Enfermagem, São Paulo, SP, Brazil.

\begin{abstract}
Objective: To verify the frequency of physical restraint in patients and the factors associated with its use in the intensive care unit. Method: An observational and prospective study on the use of restraint in patients observed over two days, considering the variables: age and gender, personal and clinical characteristics, devices, adverse event and restraint use. The frequency was verified in three groups of patients with different conditions by applying the Chi-Squared, Likelihood Ratio or Kruskal-Wallis tests. The association of the variables was verified with the Multinomial Logistic Regression. Results: Eighty-four (84) patients participated. Restraint was observed in $77.4 \%$ of the 84 analyzed patients, and was more frequent in the presence of sedation, agitation and invasive devices. The chance of being restrained was at least five times higher in sedation conditions, whether in weaning or daily awakening, mechanical ventilation weaning, agitation or the presence of invasive devices. Conclusion: Restraint use was high and was associated with female gender, sedation, agitation and invasive airway. It is emphasized and important to apply policies to reduce restraint use in intensive care.
\end{abstract}

\section{DESCRIPTORS}

Intensive Care Units; Nursing Care; Restraint Physical, Risk Management. 


\section{INTRODUCTION}

A critical patient's clinical condition, the complexity of care and the use of specialized therapeutic resources require uninterrupted vigilance in Intensive Care Units (ICUs). In this context, physical restraint (PR) is often applied to protect patients who have behavioral or consciousness changes for risk of falls, trauma, contamination, and displacement of invasive devices such as probes, drains, and catheters, which may result in treatment disruption. In addition, the use of PR may also be indicated in some situations to protect professionals providing care to these patients ${ }^{(1-2)}$.

However, the use of PR may result in adverse events (AE); therefore, it is necessary to evaluate the multidisciplinary team in order to perform the correct technique aiming toward patient safety, which includes deciding the best moment for its application and choosing the material to control the risks related to its use ${ }^{(3)}$.

In a study to analyze the use of PR by nurses in 11 ICUs in the city of El-Mansoura, Egypt, it was found that PR was used in $6.2 \%$ to $46.2 \%$ of the total of 275 patients. Of these, $19.0 \%$ to $25.3 \%$ had complications related to the use of $\mathrm{PR}$, in which hyperemia ( $16.5 \%$ to $22.4 \%$ ), contusion (2\%), ulcer $(0.4 \%$ to $0.8 \%)$ and skin necrosis $(0.1 \%)$ were observed in analyzing the lesions at the site of the device application for PR. Behavioral changes after PR were also observed: $40.5 \%$ to $48.4 \%$ of the patients started crying, $33.3 \%$ to $44.9 \%$ relaxed, and $14.6 \%$ to $18.3 \%$ became more agitated $^{(4)}$. Other studies have indicated additional negative consequences from using PR such as edema, cyanosis, bleeding from venous and arterial catheter removal, irritation, severe anxiety, respiratory complications from chest straps, and death ${ }^{(5-6)}$.

Despite the consequences of using PR, it is important to consider that its absence can also pose risks to patients such as falls. A study conducted in ICUs in the municipalities of Londrina and Maringá revealed that $16.4 \%$ of patients who had falls were not using PR devices ${ }^{(6)}$. It is noteworthy that $\mathrm{PR}$ can prevent $\mathrm{AE}$, which may prolong ICU patients' length of stay. Although PR is considered a therapeutic procedure, its application still generates controversy.

The nurse's decision to apply PR is complex and is influenced by several factors, especially ethical ones ${ }^{(7)}$. An analysis of nurses' perceptions of ethical dilemmas in applying PR revealed that $36.4 \%$ reported having difficulties in deciding on the use of $\mathrm{PR}$ due to the ethical principles of non-maleficence and beneficence ${ }^{(8)}$. In addition, it was observed that nursing team professionals sometimes performed PR without fully agreeing with the procedure indicated by the medical team professionals, as well as had differing opinions on the effectiveness of the proposed technique ${ }^{(7,9)}$.

It is noteworthy that a coherent assessment of the patient's clinical condition and multidisciplinary approach to decide on the use of PR can reduce the occurrence of AEs related to its unnecessary and abusive application, as well as ensuring care quality and protection for ICU patients. Considering the presented context and relevance of the theme, the purpose of this study is to contribute to expanding knowledge about the use of PR in ICU patients, as the topic still divides opinions and publications are scarce. Therefore, the aim of this study is to verify the frequency of $\mathrm{PR}$ in patients and the factors associated with their use in the ICU.

\section{METHOD}

\section{Study DESIGN}

This is a quantitative, observational and prospective study.

\section{SCENARIO}

The study was performed in a 17-bed general adult ICU of a university hospital located in the city of São Paulo, Brazil.

\section{Data collection}

The data collection period was from March 01 to May 31, 2015 and the selection of patients was performed considering the following inclusion criteria for the sample: age $\geq 18$ years and a six-day ICU stay, which is based on the average number of hospitalization days of the National Supplementary Health Agency of the Ministry of Health ${ }^{(10)}$.

Data from the first 20 patients of the study were considered to define the sample size. The calculation was based on the Chi-squared test (categorical variables) and T-test (continuous variables), considering a significance level of $5 \%(\alpha)$ and a test power of $80 \%(\beta)$, resulting in the need for a minimum of 76 patients in the study to compose the sample.

The variables of interest were collected daily through their own instrument with the following items: age and gender; personal characteristics (use of illicit and/or legal drugs, motor deficits and/or alteration of visual and/or hearing and/or verbal acuity); clinical condition (consciousness level- Glasgow coma scale - ECGl or sedation level - sedation and agitation scale - Richmond Agitation Sedation Scale - RASS, use of intravenous sedatives in continuous infusion, sedation weaning, daily awakening, ventilation weaning, bed agitation); devices (venous catheters, arterial catheter, epidural catheter, invasive and non-invasive airway, dressings and drains, tube feeding (TF), urinary catheter delay (UCD) and Uripen $\left.{ }^{\circledast}\right)$; adverse event and the use of PR.

Patient data were collected on the first and sixth day of hospitalization. All data were collected on the first day, called D0. The clinical condition, presence of devices and the use of PR were collected on the sixth day (D6).

The collection days were determined because the first day was considered the patient's greatest organic instability period or potential for such change. The sixth day was defined because of the average ICU stay of six days ${ }^{(10)}$.

Data processing was performed considering three groups of patients: those who had PR on both D0 and D6 were called Restrained, those who did not have PR on any of the days were called Unrestrained, and those who had only 
one day of PR were grouped as Unrestrained/Restrained or Restrained/Unrestrained (UR/R or R/UR).

The ECG1 and RASS scores evaluated at D0 and D6 were analyzed considering the variation that occurred at both moments, i.e. whether they remained the same, decreased or increased. Only patients evaluated with the same scale at both moments were included in this analysis in order to enable observing variation in the scores to compare the groups according to $\mathrm{PR}$.

\section{DATA ANALYSIS AND PROCESSING}

Categorical variables were presented as absolute and relative frequencies for data analysis by applying the Chi-squared or Likelihood Ratio tests to compare the PR groups. The mean, standard deviation and median for continuous variables were calculated using the KruskalWallis test to compare groups. The Multinomial Logistic Regression model was applied to verify the variables which were best associated with the use of PR, considering the non-restrained group as the reference category. In the simple and multiple analysis, the relationship of each independent variable was verified separately in the UR/R or $\mathrm{R} / \mathrm{UR}$ vs Unrestrained and Restrained vs. Unrestrained groups. The Stepwise method was applied to the Multiple Multinomial Logistic Regression model. A significance level of $5 \%$ ( $p$-value $<0.05$ ) and a confidence interval of $95 \%$ were considered in the tests.

\section{ETHICAL ASPECTS}

Resolution 466/2012 of the National Health Council on research with human beings was considered in performing this study. The research project was approved by the Research Ethics Committee of the Universidade Federal de São Paulo under Opinion No. 972.847/2015, with authorization for waiving the Informed Consent Form (ICF).

\section{RESULTS}

Of the 84 patients included in the sample, $51.2 \%$ were men and the mean age was 52.0 years ( $\min : 18$, max: $91, \mathrm{SD}$ : 9.8, median: 56.5). Regarding the use of PR, it was observed that a total of $65(77.4 \%)$ patients were restrained on one or both days, and 41 (48.9\%) were restrained on both D0 and D6, 19 (22.6\%) were not restrained, 18 (21.4\%) were only restrained on D0, and six (7.1\%) only on D6. The PR application site was predominantly to the upper limbs, with $88.0 \%$ on D0 and $92.0 \%$ on D6.

The three groups of patients separated according to the use of PR (Unrestrained, UR/R or R/UR and Restrained) were compared by observing the variables of age, gender, personal characteristics, level of consciousness and sedation; however, no significant differences were observed between them.

The data in Table 1 show the physical restraint groups according to the variables of clinical condition and devices, with the results indicating statistical significance.

The PR percentage was higher (65.4\%) in the group of patients with sedation on both D0 and D6, while half of the patients were not restrained in the group without sedation. All patients who were agitated on both days were restrained. Regarding the use of devices, it was found that those who used invasive airway and nasoenteral or oroenteral tube on both D0 and D6 had a higher percentage of PR: $60.5 \%$ and $64.4 \%$, respectively. Regarding the use of UCD/Uripen ${ }^{\circledast}$, $64.7 \%$ of patients with this device were restrained; however, there were patients observed without the device (66.7\%) who had PR. The variables of weaning from sedation, daily awakening, bed agitation, use of venous catheters, arterial catheter, dressings and drains, and adverse event did not present statistical differences between groups, and therefore are not presented in Table 1.

Table 1 - Patients according to physical restraint groups and the variables of clinical condition and devices - São Paulo, SP, Brazil, 2015.

\begin{tabular}{|c|c|c|c|c|}
\hline \multirow[b]{2}{*}{ Variables } & \multicolumn{3}{|c|}{ Patient Condition } & \multirow[b]{2}{*}{$\mathbf{p}^{\ddagger}$} \\
\hline & $\begin{array}{c}\text { Not } \\
\text { restrained } \\
\mathrm{n}(\%)\end{array}$ & $\begin{array}{c}\text { UR/R* or } \\
\text { R/UR } \\
\text { n (\%) } \\
\end{array}$ & $\begin{array}{l}\text { Restrained } \\
\text { n (\%) }\end{array}$ & \\
\hline \multicolumn{5}{|l|}{ Sedative } \\
\hline No & $10(50.0)$ & $4(20.0)$ & $6(30.0)$ & $0.001 \|$ \\
\hline$N / S$ or $S / N^{\S}$ & $2(5.3)$ & $18(47.4)$ & $18(47.4)$ & \\
\hline Yes & $7(26.9)$ & $2(7.7)$ & $17(65.4)$ & \\
\hline \multicolumn{5}{|c|}{ Ventilation weaning } \\
\hline No & 17 (30.9) & $14(25.5)$ & $24(43.6)$ & $0.050^{\|}$ \\
\hline $\mathrm{N} / \mathrm{Y}$ or $\mathrm{Y} / \mathrm{N}^{\S}$ & $2(7.4)$ & $10(37.0)$ & $15(55.6)$ & \\
\hline Yes & - & - & $2(100.0)$ & \\
\hline
\end{tabular}

Yes

\begin{tabular}{lcccc} 
No & $16(30.8)$ & $17(32.7)$ & $19(36.5)$ & $0.009 \|$ \\
$\mathrm{N} / \mathrm{Y}$ or $\mathrm{Y} / \mathrm{N}^{\S}$ & $3(11.1)$ & $7(25.9)$ & $17(63.0)$ & \\
Yes & - & - & $5(100.0)$ & \\
\hline
\end{tabular}

Invasive Airway

\begin{tabular}{lcccc} 
No & $9(50.0)$ & $3(16.7)$ & $6(33.3)$ & $0.00{ }^{\|}$ \\
N/Y or $Y / N^{\S}$ & $3(10.7)$ & $13(46.4)$ & $12(42.9)$ & \\
Yes & $7(18.4)$ & $8(21.1)$ & $23(60.5)$ & \\
\hline UCD $^{\natural}$ and Uripen & & & & \\
No & $1(16.7)$ & $1(16.7)$ & $4(66.7)$ & $0.001^{\|}$ \\
N/Y or $Y / N^{\S}$ & $7(25.9)$ & $16(59.3)$ & $4(14.8)$ & \\
Yes & $11(21.6)$ & $7(13.7)$ & $33(64.7)$ & \\
\hline TF** & & & & \\
No & $8(42.1)$ & $6(31.6)$ & $5(26.3)$ & $0.016^{\|}$ \\
N/Y or $Y / N^{\S}$ & $6(30.0)$ & $7(35.0)$ & $7(35.0)$ & \\
Yes & $5(11.1)$ & $11(24.4)$ & $29(64.4)$ & \\
\hline
\end{tabular}

*UR/R- Unrestrained/Restrained; ${ }^{+} \mathrm{R} / \mathrm{UR}$ - Restrained/Unrestrained; ${ }^{\ddagger} \mathrm{p}$-value; ${ }^{\S} \mathrm{N} / \mathrm{Y}$ or $\mathrm{Y} / \mathrm{N}$ - No/Yes or Yes/No; " Likelihood Ratio Test; 'UCD - Urinary Catheter Delay, ${ }^{* * T F}$ - Tube feeding.

Tables 2 and 3 show data from the Simple Multinomial Logistic Regression analysis.

In Table 2, patients had higher odds of PR on D0 or D6 if they had sedation (22.5 times), weaning from mechanical ventilation (MV) (6.1 times), central venous catheter (5.6 times) and artificial airways (13.0 times) on one of these days compared to patients without these conditions. Regarding identification of factors related to the use of $\mathrm{PR}$ in patients who were restrained on both D0 and D6, it was found that more factors were associated with the use of PR on these two days, as can be seen in Table 3 . 
Table 2 - Simple Multinomial Logistic Regression according to groups UR/R* or R/UR† and Unrestrained and independent variables - São Paulo, SP, Brazil, 2015.

\begin{tabular}{|c|c|c|c|c|}
\hline Variables & Estimate & $\mathbf{p}^{ \pm}$ & $\mathrm{OR}^{\S}$ & $\mathrm{CI}^{\prime \prime}$ \\
\hline Age & -0.003 & 0.859 & 1.0 & $0.97 ; 1.03$ \\
\hline Gender (Female vs Male) & 0.54 & 0.390 & 1.7 & $0.5 ; 5.86$ \\
\hline Drugs (Yes vs No) & -0.78 & 0.239 & 0.5 & $0.13 ; 1.68$ \\
\hline Deficits/Others (Absent vs Present) & -0.58 & 0.464 & 0.6 & $0.12 ; 2.63$ \\
\hline Sedation (N/Y or $\mathrm{Y}^{\mathrm{N}} \mathrm{N}^{\uparrow}$ vs No) & 3.11 & 0.001 & 22.5 & $3.48 ; 145.28$ \\
\hline Sedation (Yes vs No) & -0.34 & 0.736 & 0.7 & $0.1 ; 5.04$ \\
\hline Sedation weaning (N/Y or $\mathrm{Y} / \mathrm{N}^{\natural}$ vs $\left.\mathrm{No}\right)$ & 1.16 & 0.191 & 3.2 & $0.56 ; 18.16$ \\
\hline Sedation weaning (Yes vs No) & 1.67 & 0.293 & 5.3 & $0.24 ; 118.9$ \\
\hline Daily awakening (N/Y or $\mathrm{Y} / \mathrm{N}^{\star}$ vs $\left.\mathrm{No}\right)$ & 1.16 & 0.192 & 3.2 & $0.56 ; 18.16$ \\
\hline Daily awakening (Yes vs No) & 1.67 & 0.293 & 5.3 & $0.24 ; 118.9$ \\
\hline Ventilation weaning (N/Y or $\mathrm{Y} / \mathrm{N}^{`}$ vs $\left.\mathrm{No}\right)$ & 1.80 & 0.035 & 6.1 & $1.14 ; 32.41$ \\
\hline Ventilation weaning (Yes vs No) & 0.19 & 0.926 & 1.2 & $0.02 ; 64.67$ \\
\hline Agitation (N/Y or $\mathrm{Y} / \mathrm{N} \rrbracket$ vs $\mathrm{No})$ & 0.79 & 0.309 & 2.2 & $0.48 ; 9.99$ \\
\hline Agitation (Yes vs No) & -0.06 & 0.977 & 0.9 & $0.02 ; 50.32$ \\
\hline Venous catheters (N/Y or $\mathrm{Y} / \mathrm{N}^{\natural}$ vs No) & 1.72 & 0.033 & 5.6 & $1.15 ; 27.37$ \\
\hline Venous catheters (Yes vs No) & 0.00 & 1.000 & 1.0 & $0.18 ; 5.68$ \\
\hline Invasive blood pressure (N/Y or $\mathrm{Y}^{\mathrm{N}} \mathrm{N}^{`}$ vs $\mathrm{No}$ ) & 0.94 & 0.213 & 2.6 & $0.58 ; 11.38$ \\
\hline Invasive blood pressure (Yes vs No) & -0.22 & 0.801 & 0.8 & $0.14 ; 4.53$ \\
\hline Invasive Airway (N/Y or $\mathrm{Y}^{\mathrm{N}}{ }^{\natural}$ vs No) & 2.56 & 0.005 & 13.0 & $2.12 ; 79.59$ \\
\hline Invasive Airway (Yes vs No) & 1.23 & 0.144 & 3.4 & $0.66 ; 17.93$ \\
\hline Dressing and drains (N/Y or $\mathrm{Y}^{\mathrm{N}} \mathrm{N}^{\top}$ vs $\mathrm{No}$ ) & 0.29 & 0.772 & 1.3 & $0.19 ; 9.31$ \\
\hline Dressing and drains (Yes vs No) & 0.31 & 0.678 & 1.4 & $0.32 ; 5.89$ \\
\hline $\mathrm{UCD}^{* *}$ and Uripen ${ }^{\circledR}\left(\mathrm{N} / \mathrm{Y}\right.$ or $\mathrm{Y} / \mathrm{N}^{\uparrow}$ vs No) & 0.83 & 0.578 & 2.3 & $0.12 ; 41.98$ \\
\hline UCD $^{* *}$ and Uripen ${ }^{\circledR}$ (Yes vs No) & -0.45 & 0.762 & 0.6 & $0.03 ; 11.91$ \\
\hline $\mathrm{TF}^{++}\left(\mathrm{N} / \mathrm{Y}\right.$ or $\mathrm{Y} / \mathrm{N}^{\uparrow}$ vs No) & 0.44 & 0.569 & 1.6 & $0.34 ; 7.11$ \\
\hline $\mathrm{TF}^{++}$(Yes vs No) & 1.08 & 0.159 & 2.9 & $0.66 ; 13.09$ \\
\hline
\end{tabular}

* UR/R - Unrestrained/Restrained; ${ }^{\dagger} \mathrm{R} / \mathrm{UR}$ - Restrained/Unrestrained; ${ }^{\ddagger} \mathrm{p}$-value; ${ }^{\S} \mathrm{OR}$ - Odds Ratio; ${ }^{\mathrm{C}} \mathrm{Cl}-\mathrm{Confidence} \mathrm{Interval;}{ }^{\mathrm{N}} \mathrm{N} / \mathrm{Y}$ or $\mathrm{Y} / \mathrm{N}$ - No/Yes or Yes/No; ${ }^{* *}$ UCD - Urinary Catheter Delay; ${ }^{+t} \mathrm{TF}$ - Tube feeding.

Table 3 - Simple Multinomial Logistic Regression according to Restrained and Unrestrained Groups and Independent Variables - São Paulo, SP, Brazil, 2015.

\begin{tabular}{|c|c|c|c|c|}
\hline Variables & Estimate & $\mathbf{p}^{*}$ & $\mathrm{OR}^{+}$ & $\mathrm{Cl}^{\ddagger}$ \\
\hline Age & -0.01 & 0.660 & 1.0 & $0.97 ; 1.02$ \\
\hline Gender (Female vs Male) & 0.69 & 0.229 & 1.9 & $0.65 ; 6.06$ \\
\hline Drugs (Yes vs No) & 0.37 & 0.512 & 1.4 & $0.48 ; 4.33$ \\
\hline Motor deficit/others (Absent vs Present) & 0.30 & 0.704 & 1.3 & $0.29 ; 6.35$ \\
\hline Sedation $\left(\mathrm{N} / \mathrm{Y}\right.$ or $\mathrm{Y} / \mathrm{N}^{\S}$ vs $\left.\mathrm{No}\right)$ & 2.71 & 0.003 & 15.0 & $2.54 ; 88.7$ \\
\hline Sedation (Yes vs No) & 1.40 & 0.041 & 4.0 & $1.06 ; 15.48$ \\
\hline Sedation weaning (Yes vs No) & 1.27 & 0.421 & 3.6 & $0.16 ; 79.1$ \\
\hline Daily awakening (N/Y or $\mathrm{Y} / \mathrm{N}^{\S}$ vs $\left.\mathrm{No}\right)$ & 1.67 & 0.041 & 5.3 & $1.07 ; 26.34$ \\
\hline Daily awakening (Yes vs No) & 1.27 & 0.421 & 3.6 & $0.16 ; 79.1$ \\
\hline Ventilation weaning $\left(\mathrm{N} / \mathrm{Y}\right.$ or $\mathrm{Y} / \mathrm{N}^{\S}$ vs $\left.\mathrm{No}\right)$ & 1.67 & 0.041 & 5.3 & $1.07 ; 26.34$ \\
\hline Ventilation weaning (Yes vs No) & 1.27 & 0.421 & 3.6 & $0.16 ; 79.1$ \\
\hline Agitation $\left(\mathrm{N} / \mathrm{Y}\right.$ or $\mathrm{Y} / \mathrm{N}^{\S}$ vs $\left.\mathrm{No}\right)$ & 1.56 & 0.028 & 4.8 & $1.18 ; 19.27$ \\
\hline Agitation (Yes vs No) & 2.23 & 0.141 & 9.3 & $0.48 ; 181.14$ \\
\hline Venous catheters $\left(\mathrm{N} / \mathrm{Y}\right.$ or $\mathrm{Y} / \mathrm{N}^{\S}$ vs $\left.\mathrm{No}\right)$ & 0.40 & 0.559 & 1.5 & $0.39 ; 5.74$ \\
\hline Venous catheters (Yes vs No) & -0.41 & 0.547 & 0.7 & $0.18 ; 2.49$ \\
\hline Invasive blood pressure $\left(\mathrm{N} / \mathrm{Y}\right.$ or $\mathrm{Y} / \mathrm{N}^{\S}$ vs $\left.\mathrm{No}\right)$ & 0.16 & 0.819 & 1.2 & $0.31 ; 4.46$ \\
\hline Invasive blood pressure (Yes vs No) & 0.31 & 0.658 & 1.4 & $0.35 ; 5.38$ \\
\hline Invasive airway (N/Y or $\mathrm{Y} / \mathrm{N}^{\S}$ vs $\left.\mathrm{No}\right)$ & 1.79 & 0.031 & 6.0 & $1.17 ; 30.72$ \\
\hline Invasive airway (Yes vs No) & 1.60 & 0.019 & 4.9 & $1.3 ; 18.73$ \\
\hline Dressing and drains ( $\mathrm{N} / \mathrm{Y}$ or $\mathrm{Y} / \mathrm{N}^{\S}$ vs $\left.\mathrm{No}\right)$ & -0.82 & 0.353 & 0.4 & $0.08 ; 2.49$ \\
\hline Dressing and drains (Yes vs No) & -0.90 & 0.156 & 0.4 & $0.12 ; 1.41$ \\
\hline UCD" and Uripen ${ }^{\circledR}\left(\mathrm{N} / \mathrm{Y}\right.$ or $\mathrm{Y} / \mathrm{N}^{\S}$ vs $\left.\mathrm{No}\right)$ & -1.95 & 0.129 & 0.1 & $0.01 ; 1.76$ \\
\hline UCD $^{\|}$and Uripen ${ }^{\circledR}$ (Yes vs No) & -0.29 & 0.806 & 0.7 & $0.08 ; 7.44$ \\
\hline $\mathrm{TF}^{\S}\left(\mathrm{N} / \mathrm{Y}\right.$ or $\mathrm{Y} / \mathrm{N}^{\S}$ vs No) & 0.62 & 0.433 & 1.9 & $0.39 ; 8.89$ \\
\hline TF` (Yes vs No) & 2.23 & 0.003 & 9.3 & $2.14 ; 40.2$ \\
\hline
\end{tabular}

${ }^{*} \mathrm{p}$-value, ${ }^{\dagger} \mathrm{OR}$ - Odds Ratio, ${ }^{\ddagger} \mathrm{Cl}$ - Confidence Interval, ${ }^{\mathrm{s}} \mathrm{N} / \mathrm{Y}$ or $\mathrm{Y} / \mathrm{N}-\mathrm{No} / \mathrm{Yes}$ or Yes/No, $\mid$ UCD - Urinary Catheter Delay, ${ }^{\circledR} \mathrm{TF}-\mathrm{Tube}$ feeding. 
The data in Table 3 show that patients who used sedatives on D0 or D6 were 15 times more likely to be restrained than patients who did not use sedation. The chance of PR was four times higher for those who used sedatives on both days compared to those who were not sedated. Patients with invasive airway on D0 or D6 were six times more likely to be restrained. The restraining chance was 4.9 times higher for those with invasive airway on both days compared to those who did not have an invasive airway.
Furthermore, the chance of PR was 9.3 times higher in patients with TF on D0 and D6. Patients had higher chances of PR if they were weaning from sedation (5.3 times), had daily awakening (5.3 times), MV weaning (5.3 times) or agitation (4.8 times) on D0 or D6 compared to patients without these conditions.

The factors associated with the use of PR in the different groups in the multiple multinomial regression are presented in Table 4.

Table 4 - Multiple Multinomial Logistic Regression according to physical restraint groups and independent variables - São Paulo, SP, Brazil, 2015.

\begin{tabular}{|c|c|c|c|c|}
\hline Variables & Estimate & $\mathrm{p}^{*}$ & $\mathrm{OR}^{+}$ & $\mathrm{CI}^{ \pm}$ \\
\hline \multicolumn{5}{|l|}{ UR/R or $R /$ UR $^{\S}$ vs Unrestrained } \\
\hline Gender (Female vs Male) & 1.50 & 0.130 & 4.5 & $0.64 ; 31.59$ \\
\hline Sedation (N/S or Y/N" vs No) & 2.68 & 0.019 & 14.6 & $1.56 ; 137.32$ \\
\hline Sedation (Yes vs No) & -3.51 & 0.140 & 0.03 & $0.0003 ; 3.15$ \\
\hline Agitation (N/Y or $\mathrm{Y} / \mathrm{N} \|$ vs No) & 1.50 & 0.197 & 4.5 & $0.46 ; 43.29$ \\
\hline Agitation (Yes vs No) & -0.06 & 0.977 & 0.9 & $0.02 ; 50.32$ \\
\hline Invasive Airway (N/Y or Y/N"| vs No) & 3.01 & 0.023 & 20.3 & $1.52 ; 272.62$ \\
\hline Invasive Airway (Yes vs No) & 5.48 & 0.022 & 239.3 & $2.19 ; 26185.98$ \\
\hline \multicolumn{5}{|l|}{ Restrained vs Unrestrained } \\
\hline Gender (Female vs Male) & 2.38 & 0.015 & 10.8 & $1.59 ; 73.57$ \\
\hline Sedation (N/Y or $\mathrm{Y} / \mathrm{N} \|$ vs No) & 3.06 & 0.021 & 21.2 & $1.58 ; 284.72$ \\
\hline Sedation (Yes vs No) & 0.26 & 0.906 & 1.3 & $0.02 ; 93.82$ \\
\hline Agitation (N/Y or Y/N"l vs No) & 2.99 & 0.007 & 19.8 & $2.25 ; 173.76$ \\
\hline Agitation (Yes vs No) & 2.23 & 0.141 & 9.3 & $0.48 ; 181.14$ \\
\hline Invasive Airway (N/Y or Y/N\| vs No) & 3.39 & 0.020 & 29.7 & $1.71 ; 515.11$ \\
\hline Invasive Airway (Yes vs No) & 4.27 & 0.068 & 71.5 & $0.73 ; 7040.65$ \\
\hline
\end{tabular}

According to Table 4 in considering the group of patients who were restrained on D0 or D6 (UR/R or R/UR) and the unrestrained group, the factors identified for using $P R$ were the presence of sedation on one of the evaluation days and the use of invasive airway.

When considering the group of restrained and unrestrained patients, the factors related to the use of $\mathrm{PR}$ were female gender, sedation, agitation and invasive airway on one of the evaluation days. A very wide confidence interval of the factors identified in the two models is emphasized.

\section{DISCUSSION}

PR application on patients is mostly performed by the nurse who assesses the need for its use and removal ${ }^{(11)}$. Studies show a wide variation in the frequency of PR use in critically ill patients worldwide, from $3.5 \%$ to $87 \% \%^{(2,8,12-13)}$. The frequency of PR use in patients was high in the ICU under study. It is noteworthy that the reduced use of PR is considered an important indicator for nursing care quality and has been a concern of nurses regarding an evaluation of its indication and implementing programs aimed at reducing its use ${ }^{(12,14)}$.

Factors associated with the use of PR in the study sample were sedation, presence of agitation, invasive airway use, and female gender. In the results of the analysis of PR use in 25 ICUs in the Netherlands, the identified factors were delirium, comatose state, sedative use and communication disability $^{(14)}$. Other predictive factors for PR use identified in clinical, surgical and ICU units of an Israeli hospital were the presence of nasogastric catheter, urinary catheter delay, endotracheal tube and the presence of pressure injury ${ }^{(13)}$. In a systematic review which analyzed the prevalence of PR in the ICU, the presence of invasive devices, delirium and risk of falling were identified as conditions related to their use in 27 studies $^{(12)}$.

The use of $\mathrm{PR}$ in the presence of therapeutic devices is intended to prevent accidental withdrawal aiming for patient safety, especially when their consciousness level is altered and there is agitation. According to a Dutch multicenter study, the most common reasons for applying the restraint were a possible threat to the catheter or endotracheal tube becoming displaced ${ }^{(13)}$. This factor may have influenced the decision on PR use during nursing care provided to patients included in this study. In an analysis on the differences between the groups studied regarding the use of devices, significant differences were also verified in the use of UCD and $\mathrm{TF}$, in addition to the presence of the invasive airway.

Coexistence of agitation in critically ill patients and presence of PR is frequently observed in the ICU. A multicenter prospective observational study conducted in three Swiss ICUs showed that agitation, insufficient sedation and its weaning are directly related to PR use ${ }^{(15)}$. In a French study conducted in $121 \mathrm{ICUs}$, the use of $\mathrm{PR}$ in patients under mechanical ventilation was more frequent in patients weaning from sedation and intense agitation, and was not observed in deep sedation. In this study, the time patients remained restrained was greater than $50 \%$ of the time of MV use in $65 \%$ of ICUs ${ }^{(1)}$. PR use is more commonly observed in MV patients, as they undergo daily awakening, sedation 
weaning or ventilation, which can cause discomfort, leading to agitation and consequent accidental removal of the endotracheal tube $\mathrm{e}^{(1-2,16)}$.

The use of $\mathrm{PR}$ in agitation and weaning situations in critically ill patients can be considered a safety factor. A Swiss study conducted in three ICUs which analyzed the use of $\mathrm{PR}$ to prevent $\mathrm{AE}$ occurrence showed that patients with $\mathrm{PR}$ had lower $\mathrm{AE}$ occurrence compared to those who did not use it (26 vs $60 \mathrm{p}<0.021)^{(15)}$.

However, PR alone is not a guarantee to avoid AE. The occurrence of unplanned extubation and catheter removal in ICU PR patients was observed in a systematic review. On the other hand, the use of PR may lead to intensified patient agitation and result in damage and worsening of their clinical condition ${ }^{(12)}$.

The risk of AE occurrence may favor the nurse's attitude toward maintaining $\mathrm{PR}$ in patients with low risk of agitation and even in sedated patients. PR use was observed in French and Dutch ICUs in sedated patients using psychoactive drugs who were in a calm and quiet or a comatose state ${ }^{(13)}$. In this study, PR use was found in most patients (65.4\%) with sedatives (Table 1), regardless of the variation in the RASS score in the two observed moments. Other aspects to consider in using and maintaining PR may be related to the high proportion of patients per nurse, night time and absence of companions or family members ${ }^{(1-2)}$.

Frequent bedside care by the nursing team to critically ill patients leads these professionals to assess the need for PR. In this context, the responsibility for the occurrence and consequences of inadvertent removal of catheters, probes or tubes from the patient often lies with the nursing staff, and so there is a reluctance to remove $\mathrm{PR}$ even in cases of low risk of $\mathrm{AE}$. The existence of a protocol for the multidisciplinary team to evaluate the conditions which require the use of $\mathrm{PR}$ would favor sharing the responsibility and may even reduce its use ${ }^{(12,16)}$.

Nurses' use of the Decision Support Tool called the Restraint Decision Wheel (RDW) was analyzed in a quasi-experimental study conducted in a medical-surgical ICU to determine if $\mathrm{PR}$ could be reduced without harming patients. The results showed a $32 \%$ reduction in PR without an increase in unplanned removal of therapeutic devices or harm to patients ${ }^{(14)}$.

For the culture of reducing the use of $\mathrm{PR}$, in-service education for nurses should include patient rights, indications and alternatives for restraint (i.e. boxing gloves), documentation, and the use of tools which can assist in decision-making ${ }^{(15)}$. Implementing training programs can enable health teams on how to apply PR to patients and its AEs, as well as the use of other strategies and alternatives to control aggressive behavior and patient relaxation prior to $\mathrm{PR}^{(17-19)}$. Although $\mathrm{PR}$ use aims to maintain patient safety, the physical, mental and legal consequences should be considered by nurses and other members of the multidisciplinary team ${ }^{(12)}$.

The female gender was also identified in the sample of this study as a factor associated with PR use. However, the prevalence of PR was observed in both women and men. In a study which identified the highest prevalence in women hospitalized in different inpatient units, the increased risk of $\mathrm{PR}$ in females was not found in the logistic regression model ${ }^{(20)}$. The highest frequency and prevalence of male PR was observed in a study conducted in hospitals in the United States of America and in another study conducted at a medical center in Israel. Data collection in both studies was performed in all hospitalization units, including ICUs ${ }^{(2,21)}$. Despite the significant results of these studies, the fact that they were found in units with different characteristics from the ICU makes it difficult to analyze the association of PR use in critically ill patients considering the characteristics related to the gender variable ${ }^{(2,21)}$.

The analysis of the results led to finding limitations of this study related to sample size, data collection in a single ICU, observation of the presence of PR on two separate days instead of the total time having $P R$, and the fact that a group of patients whose condition of restraint varied at both data collection times was considered. Aspects related to the number of professionals and nursing workload, as well as the reasons for the PR use, time of day, existence of medical prescription and the PR registered in the patient's medical record are factors of interest for developing new analyzes.

\section{CONCLUSION}

The results allowed us to conclude that $77.4 \%$ of the patients had PR on one or both days evaluated. Factors related to the PR use in the ICU were female gender, sedation, agitation and invasive airway. The findings of this study may support and arouse interest for conducting national studies on PR in ICU patients in order to better understand this practice in the Brazilian context. Considering the importance of policies to reduce PR in the ICU, the need to develop appropriate protocols and instruments based on the best scientific evidence is emphasized so as to assist the multidisciplinary team in evaluating the patient regarding PR use.

\section{RESUMO}

Objetivo: Verificar a frequência de restrição mecânica nos pacientes e os fatores associados ao seu uso na Unidade de Terapia Intensiva. Método: Estudo observacional e prospectivo sobre uso da restrição em pacientes, observados em dois dias, considerando as variáveis: idade e sexo, características pessoais e clínica, dispositivos, evento adverso e uso de restrição. A frequência foi verificada em três grupos de pacientes com diferentes condições aplicando-se os testes Qui-Quadrado ou Razão de Verossimilhança ou Kruskal-Wallis. A associação das variáveis foi verificada com a Regressão Logística Multinomial. Resultados: Participaram 84 pacientes. A restrição foi observada em $77,4 \%$ dos 84 pacientes analisados e foi mais frequente na presença de sedação, agitação e dispositivos invasivos. A chance de se estar restrito foi cerca de pelo menos cinco vezes maior nas condições de sedação, seja em desmame ou despertar diário, desmame da ventilação mecânica, agitação e presença de dispositivos invasivos. Conclusão: $\mathrm{O}$ uso da restrição foi elevado e associou-se ao sexo feminino, sedação, agitação e via aérea invasiva. Ressalta-se a importância de aplicação de políticas para redução da restrição em terapia intensiva.

\section{DESCRITORES}

Unidades de Terapia Intensiva; Cuidados de Enfermagem; Restrição Física, Gestão de Riscos. 


\section{RESUMEN}

Objetivo: Verificar la frecuencia de restricción mecánica en los pacientes y los factores asociados con su empleo en la Unidad de Cuidados Intensivos. Método: Estudio observacional y prospectivo acerca del uso de la restricción en pacientes, observados en dos días, considerando las variables: edad y sexo, características personales y clínicas, dispositivos, evento adverso y empleo de restricción. La frecuencia fue verificada en tres grupos de pacientes con distintas condiciones, aplicándose las pruebas Chi cuadrado o Razón de Verosimilitud o Kruskal-Wallis. La asociación de las variables fue verificada con la Regresión Logística Multinomial. Resultados: Participaron 84 pacientes. La restricción fue observada en el 77,4\% de los 84 pacientes analizados y fue más frecuente en la presencia de sedación, agitación y dispositivos invasivos. La probabilidad de estar restricto fue por lo menos cinco veces mayor en las condiciones de sedación, ya sea en la reducción gradual de la medicación o despertar diario, reducción gradual de la ventilación mecánica, agitación y presencia de dispositivos invasivos. Conclusión: El empleo de la restricción fue elevado y se asoció con el sexo femenino, sedación, agitación y vía aérea invasiva. Se subraya la importancia de aplicación de políticas para reducción de la restricción en cuidados intensivos.

\section{DESCRIPTORES}

Unidades de Cuidados Intensivos; Atención de Enfermería; Restricción Física, Gestión de Riesgos.

\section{REFERENCES}

1. Constantin JM e Lefrant JY, Chanques G, Capdevila X, Lefrant J-Y, Outin H, et al. Physical restraint in mechanically ventilated ICU patients: a survey of French practice. Intensive Care Med. 2013 Jan 39(1):31-7. DOI: 10.1007/s00134-012-2715-9.

2. Raguan B, Wolfovitz E, Gil E. Use of physical restrain in a general hospital: a cross sectional observational study. Isr Med Assoc J. 2015;17(10):633-8.

3. Rose L, Daile C, Smith O, Enright G, Fergusson D, Sinha S. A mixed-methods systematic review protocol to examine the use of physical restraint with critically ill adults and strategies for minimizing their use. Syst Rev. 2016;5:194. DOI: 10.1186/s13643-016-0372-8.

4. Kandeel NA, Attia AK. Physical restraints practice in adult intensive care units in Egypt. Nurs Health Sci. 2013;15(1):79-85. DOI: 10.1111/ nhs. 12000 .

5. Decesaro MN, Padilha KG. Queda: comportamentos negativos de enfermagem e consequências para o paciente durante o período de internamento em UTI. Arq Ciênc Saúde UNIPAR. [Internet]. 2001 [citado 2017 fev. 20];5(2):115-25. Disponível em: http://revistas.unipar. br/index.php/saude/article/view/1115/978

6. De Casterlé BD, Goethals S, Gastmans C. Contextual influences on nurses' decision-making in cases of physical restraint. Nurs Ethics. 2015;22(6):642-51. DOI: 10.1177/0969733014543215

7. Yönt $\mathrm{GH}$, Korhan EA, Dizer B, Gümüş F, Koyuncu R. Examination of ethical dilemmas experienced by adult intensive care unit nurses in physical restraint practices. Holist Nurs Pract. 2014;28(2):85-90. DOI: 10.1097/HNP.0000000000000013

8. Rose L, Burry L, Mallick R, Luk E, Cook D, Fergusson D, et al. Prevalence, risk factors, and outcomes associated with physical restraint use in mechanically ventilated adults. J Crit Care. 2016;31(1):31-5. DOI: 10.1016/j.jcrc.2015.09.011

9. Paes MR, Borba LO, Maftum MA. Contenção física de pessoas com transtorno mental: percepções da equipe de enfermagem. Ciênc Cuid Saúde. 2011;10(2):240-247. DOI: 10.4025/cienccuidsaude.v10i2.9295

10. Brasil. Ministério da Saúde; Agência Nacional de Saúde Suplementar. Média de permanência em UTI adulto [Internet]. Brasília; 2013 [citado 2018 fev. 01]. Disponivel em: http://www.ans.gov.br/images/stories/prestadores/E-EFI-08.pdf

11. Luk E, Burry L, Rezaie S, Mehta S, Rose L. Critical care nurses' decisions regarding physical restraints in two Canadian ICUs: a prospective observational study. Can J Crit Care Nurs. 2015;26(4):16-22.

12. Mahtabeh A, Mahmood M, Ravanbakhsh E. Use of physical restraints in intensive care unit: a systematic review study. Acta Med Mediter. 2017;33:129-36. DOI: 10.19193/0393-6384_2017_1_020

13. Van der Kooi AW, Peelen MA, Raijmakers RJ, Vroegop RL, Bakker DF, Tekatli H, et al. Use of physical Restraints in Dutch Intensive care units: a prospective multicenter study. Am J Crit Care. 2015;24(6):488-95. DOI: http://dx.doi.org/10.4037/ajcc2015348

14. Stacy H, Barbara R, Toby M. Using a decision wheel to reduce use of restraints in a medical-surgical intensive care unit. Am J Crit Care. 2016;25(6):479-86 DOI: 10.4037/ajcc2016929

15. Perren A, Corbella D, lapichino E, Di Bernardo V, Leonardi A, Di Nicolantonio R, et al. Physical restraint in the ICU: does it prevent device removal? Minerva Anestesiol. 2015;81(10):1086-95.

16. Benbenbishty J, Adam S, Endacott R. Physical restraint use in intensive care units across Europe: the PRICE study. Intensive Crit Care Nurs. 2010;26(5):241-5. DOI: 10.1016/j.iccn.2010.08.003

17. Yeh SH, Hsiao CY, Ho TH, Chiang MC, Lin LW, Hsu CY, et al. The effects of continuing education in restraint reduction on novice nurses in intensive care units. J Nurs Res. 2004;12(3):246-56.

18. Huang HT, Chuang YH, Chiang KF. Nurses' physical restraint knowledge, attitudes, and practices: the effectiveness of an in-service education program. J Nurs Res. 2009;17(4):241-8. DOI: 10.1097/JNR.0b013e3181c1215d

19. Jiang H, Li C, Gu Y, He Y. Nurses' perceptions and practice of physical restraint in China. Nurs Ethics. 2015;22(6):652-60. DOI: $10.1177 / 0969733014557118$

20. Heinze C, Dassen T, Grittner U. Use of physical restraints in nursing homes and hospitals and related factors: a cross-sectional study. J Clin Nurs. 2012;21(7-8):1033-40. DOI: 10.1111/j.1365-2702.2011.03931.x.

21. Minnick AF, Mion LC, Johnson ME, Catrambone C, Leipzig R. Prevalence and variation of physical restraint use in acute care settings in the US. J Nurs Scholarsh. 2007;39(1):30-7. 